Ebselen (DR-3305)の代謝と抗酸化作用

○増元 浩、橋本 浩一、中岡 稔、伯水 英夫 第一製薬(侏) 開発研究所

\title{
METABOLISM OF EBSELEN (DR-3305) : RELATION TO THE ANTIOXIDANT ACTIVITY
}

Hiroshi MASUMOTO, Kouichi HASHIMOTO, Minoru NAKAOKA and Hideo HAKUSUI

Developmental Research Laboratories

Daiichi Pharmaceutical Co., Ltd., Tokyo 134

【目的】Ebselen (2-phenyl-1,2-benzisoselenazol-3(2H)-one, DR-3305) はグル タチオンペルオキシデース (GSH-Px) の活性中心をモデルとして合成された GSH-Px様活性を有するセレン $(\mathrm{Se})$ 含有の抗酸化剤である(1-4)。本薬の抗酸化 作用および薬効は詳細に検討されている $(3,4)$ 。Ebselenは溶液中でアルブミン 等のタンパクチオール $(\mathrm{SH})$ 基とほぼ定量的に反応し、自身は還元的に開環 して特徴的なセレノスルフィド (Se-S) 結合による付加体 (Se-S complex) を形 成する(5)。また、ebselen経口投与後のラット血漿、尿、胆汁中には未変化体 は観測されず、血槳中では血槳タンパクと可逆的にSe-S complexを形成し、 このSe-S complexが主要代謝物として認められた(6)。本薬はさらにメチル化、 水酸化、グルクロン酸抱合を受け(7)、速やかに尿および胆汁中に排泄される が、これら排泄型代謝物はいずれも主薬理作用を持たない。これらの知見を 踏まえ、本研究では経口投与後の生体内で実質的な抗酸化活性を担う本薬の 活性本体を解明することを目的とし、種々の検討を試みた。

\section{【方法】1.)実験材料.}

Ebselen, ebselenのS-アナ

ログ(PZ-25)および既知 代謝物標品はRhône-

Poulenc-Nattermann社、 ${ }^{14}$ C-ebselenは第一化学 薬品(株においててれぞ れ合成された。Ebselen とBSAあるいは14 Cebselen とBSAとのSe-S complexは両者を水溶液 中反応後、ゲル濾過法

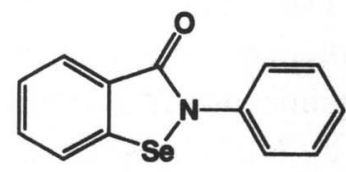

Ebselen (DR-3305)

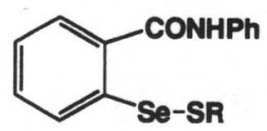

$\begin{aligned} \text { RSH }= & \text { proteln (Se-S complex) } \\ \text { GSH } & \text { (Se-SG) } \\ \text { Cys } & \text { (Se-Cys) }\end{aligned}$

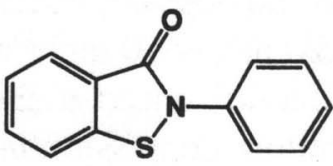

PZ-25

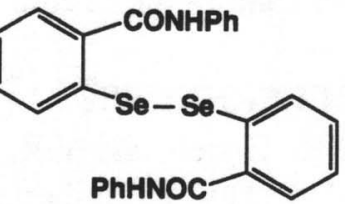

Se-Se dimer 
で精製し、凍結乾燥品を得た。他のebselen誘導体は既知の方法で合成した。 2.) GSH-Px様活性の測定. NADPH, GSHおよびGSSG還元酵素存在下、室温 で被験物質と種々のハイドロペルオキシド類 $(\mathrm{ROOH})$ を基質として反応させ、 ROOHの還元にともなうNADPHの消費速度を観測した。

3 .) 動物実験. SD系雄性ラット ( 8 週齢)に ${ }^{14}$ C-ebselenを経口投与し $(200 \mathrm{mg} / \mathrm{kg})$ 、 投与後 4 時間の脂肪組織を採取した。

4.) 脂肪中代謝物の単離と分析. 代謝物は脂肪から有機溶媒抽出後、シリカ ゲルカラムクロマトグラフィーで単離精製した。サンプルはODS系LCカラム を装着したLC/MSシステム(Finnigan MAT)を用いて分析した。

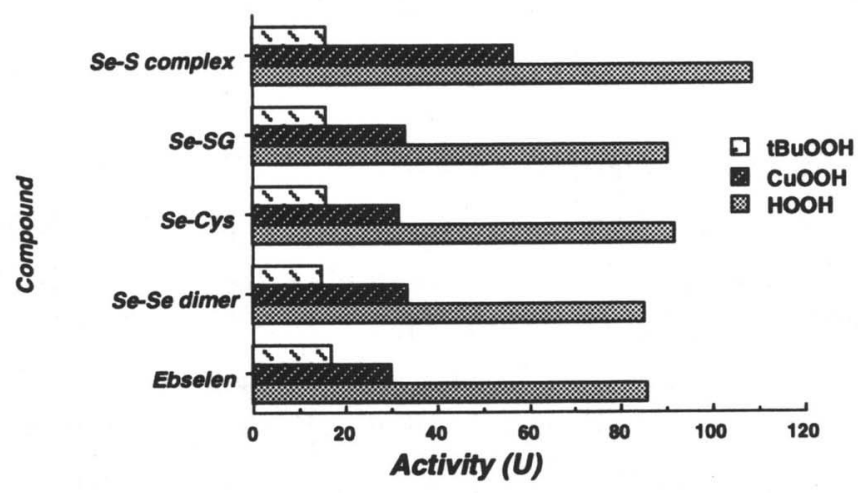

Figure 1. GSH-PX-like activity of ebselen and its derivatives.

A mixture of EDTANa2 (1 mM), NaN3 (1 mM), GSH (1 mM), NADPH $(250$ $\mu M)$, test compound $(50 \mu M$ equiv. of Se), GSSG reductase (1 unit/mI and $\mathrm{ROOH}(1 \mathrm{mM})$ in potassium phosphate buffer $(50 \mathrm{mM}, \mathrm{pH} 7.4)$ was incubated at room temperature. Activity (unit $=1 \mu M$ NADPH consumption/min) was calculated from $\triangle A_{340} / \mathrm{min}$. ROOH: hydrogen peroxide (HOOH), cumene hydroperoxide (CuOOH), or tert-butyl hydroperoxide.

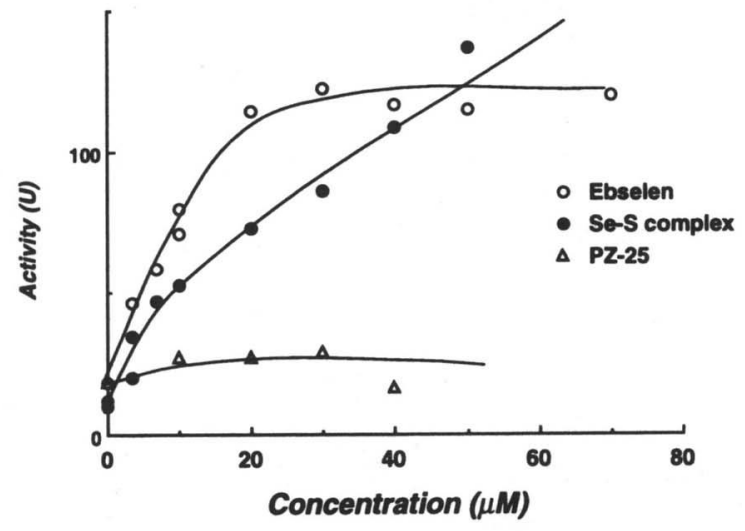

Figure 2. GSH-PX-like activity versus concentration.

Various concentrations of test compounds were incubated with $\mathrm{HOOH}$ in a similar manner as shown in Fig. 1. Values included background level. 


\section{【結果と考察】}

Ebselen セレノスルフィド (Se-S) 誘導体のGSH-Px様活性:

Ebselenが生体内では主にSe-S complexを形成していることに注目し、 このGSH-Px 様活性を ebselenのそれと比較検討した。その結果、selenoglutathione体 (Se-SG)、selenocysteine体 (Se-Cys)、 diselenide体 (Se-Se dimer)およ びアルブミンとのSe-S complexはebselenとほほ同等の活性を示した(Fig. 1)。 特にSe-S complexは水溶性が高く、水系において濃度に比例したGSH-Px様活 性を示した。一方、脂溶性が高いebselen自体の活性は20-30 $\mu \mathrm{M}$ で飽和した (Fig. 2)。以上から、 diselenideあるいはselenosulfide結合を有する ebselen誘導体 はebselenと同様のGSH-Px様活性を有することが明らかとなった。

脂肪中代謝物の検索と同定:

${ }^{14} \mathrm{C}-$ Ebselen 経口投与後に放射能が高濃度に分布する脂肪中で 2 種類の主 要新規代謝物が見いだされた。そこで、これらを単離し構造解析を行ったと ころ、これら代謝物は2-(methylseleninyl)benzanilide (Se(O)Me) および ebselen Se-oxide (SeOx) であると同定された(Fig. 3)。これらは血漿中や胆汁中の主要 代謝物の 1 つである selenomethyl体 (Se-Me)およびebselenのSe部位がそれぞれ 酸化されて生成したと考えられる(8-10)。興味深いことにSe(O)Meの単離品を 溶液中放置すると、この標品の熱分解時と同様に、親化合物である ebselenお よびSeOxを与えた。またSeOxはGSHで還元されてebselenに復帰する(10)。す なわち、これら両代謝物は親化合物である ebselenに復帰しうること(Fig. 3)が 確認され、ebselenの抗酸化作用においても関与しうることが推定された。

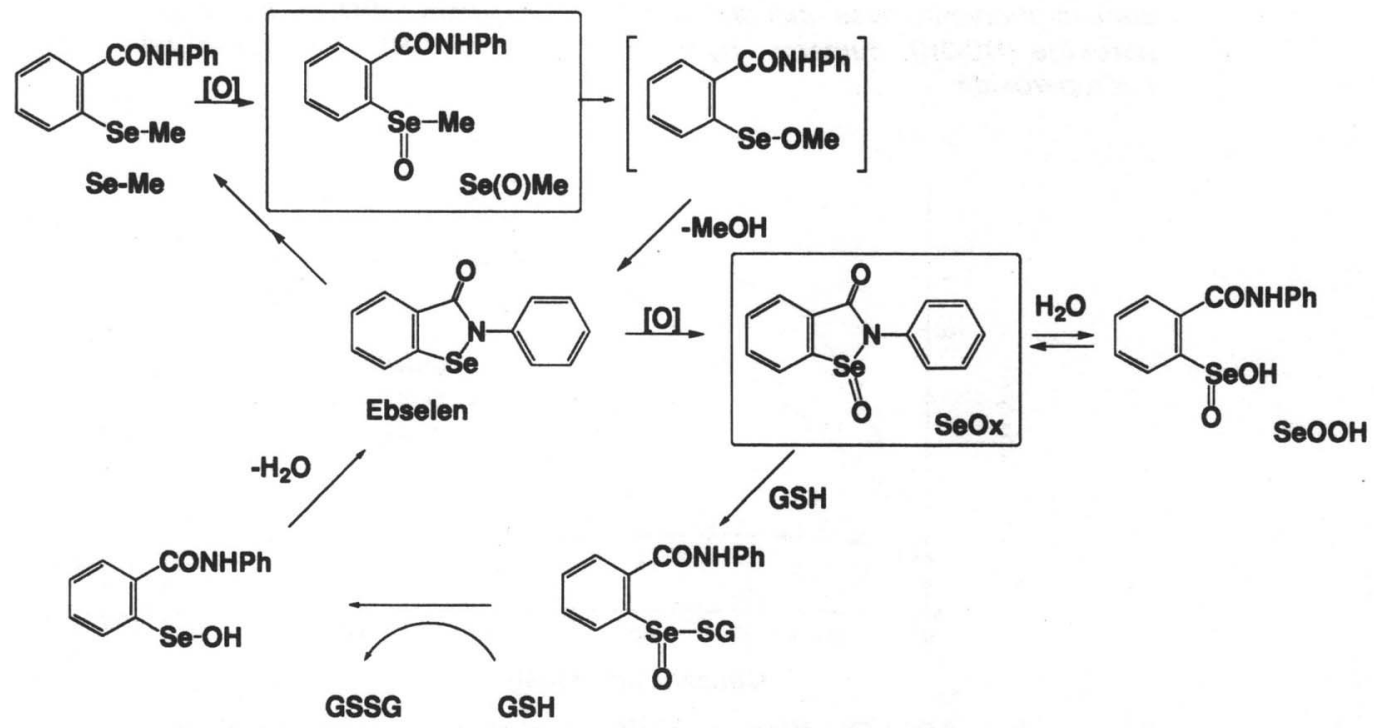

Figure 3. Postulated metabolic pathway of ebselen. 
【まとめ】Ebselenの生体内での抗酸化作用には、水系で抗酸化作用を示 すチオールタンパクとのSe-S complexの存在が、また脂質系においては ebselenに復帰しうる酸化型代謝物の存在が主として関与すると推定された。

\section{[Abstract]}

Ebselen, 2-phenyl-1,2-benzisoselenazol-3(2H)-one, is a selenoorganic antioxidant with glutathione peroxidase (GSH-Px)-like activity. After oral administration, ebselen reacted with thiol group of plasma proteins (albumin) in rat, forming a selenosulfide complex (Se-S complex) and unchanged ebselen was hardly found. We focused on the GSH-Px-like activity of the complex itself. Se-S complex prepared from ebselen and BSA showed GSH-Px-like activity towards hydroperoxides. Other selenosulfide and diselenide derivatives as well as ebselen showed similar GSH-Px-like activity to that of the complex. Ebselen is extensively metabolized in vivo, and authentic samples of main urinary and biliary metabolites have no antioxidant activities. We therefore investigated metabolic patterns in tissues and found two polar unknown metabolites in rat fat. These metabolites were isolated, analyzed by HPLC/MS, and identified as ebselen Se-oxide (SeOx) and 2-(methylseleninyl)benzanilide $(\mathrm{Se}(\mathrm{O}) \mathrm{Me})$. SeOx can be reduced back to ebselen by reductant such as GSH. Interestingly, the isolated $\mathrm{Se}(\mathrm{O}) \mathrm{Me}$ afforded ebselen and its Se-oxide in a solution left standing. Either metabolite can revert to ebselen. Se-S complex as well as these metabolites are possibly responsible for the pharmacological activity shown by oral dose of ebselen in vivo.

\section{[References]}

(1) Müller, A. et al., Biochem. Pharmacol., 33 , 3235-3239 (1984).

(2) Wendel, A. et al., Biochem. Pharmacol., 33 , 3241-3245 (1984).

(3) Sies, H. et al., Free Rad. Biol. Med., 14, 313-323 (1993).

(4) Schewe, T. et al., Gen. Pharmacol. in press (1995).

(5) Nomura, H. et al., In:Selenium in Biology and Medicine (Wendel, A.,Ed.), pp.189-193,Springer Verlag, Heidelberg (1989).

(6) 増元ら, 日本薬学会第113年会講演要旨, 115 (1993).

(7) Fischer, H. et al., Xenobiotica, 18, 1347-1359 (1988).

(8) John, N. J. et al., Chem. Res. Toxicol., 3, 199-203 (1990).

(9) Ziegler, D. M. et al., Chem. Res. Toxicol., 5, 163-166 (1992).

(10)Fischer, H. and Dereu, N., Bull. Soc. Chim. Berg., 9 6, 757-768 (1987). 